Trawlermen have a fatalistic attitude to sickness and death and pay little attention to safety devices or their own sickness. Health education is needed, and an industrial medical officer should also supervise the first-aid training of skippers and mates, who should attend courses throughout their period of service at sea.

The health and safety of trawlermen are still the subject of much public concern. The interim report of the Board of Trade's Committee of Inquiry which was set up after last winter's three trawler disasters recommended the provision of a support ship to the fishing fleet in the area north of Iceland. The Orsinoe has been at sea throughout the winter carrying meteorological staff, a medical officer, and sick berth attendant, and the results of this innovation will be of great interest ; but only when real changes have been made in conditions at sea will there be a fall in the excessively high mortality rate of fishermen.

\section{Boarding Out}

The adverse effect on patients of prolonged care in large institutions is now well established. Thus it was hardly surprising that the Royal Commission on the Law Relating to Mental Illness and Mental Deficiency, 1957, looked critically on the mental hospitals and supported the concept of community care. The Mental Health Act, 1959, led to the establishment by local health authorities of various types of accommodation for the mentally disordered, including longstay psycho-geriatric hostels, ${ }^{1}$ short-stay hostels, ${ }^{2}$ and boarding out with private landladies. The last practice was not new. Indeed, in 1856 Bucknill, at Devon County Lunatic Asylum, instituted such a scheme for the mentally ill, based on the considerably older system at Gheel in Belgium, and for many years voluntary organizations like the Guardianship Society and the Mental After-care Association had boarded out both the mentally ill and the mentally subnormal.

In his annual report for 1967 the medical officer of health for Exeter ${ }^{3}$ states that many mentally disordered persons may be placed in lodgings provided the landladies are chosen with care and adequate social work support is given. In that city in 1967 there were 112 such people in lodgings, about half of whom were in open employment. Difficulties arose over the low wage obtained ( $£ 6-£ 7$ a week) and the cost of lodgings ( $£ 55 \mathrm{~s}$. a week.) These difficulties have been overcome at Croydon ${ }^{4}$ by the local authority subsidizing the rent of the patients living with private landladies. There a wholetime boarding-out officer was appointed in 1962, whose job was to assess accommodation and match the landlady to the patient. The latter paid directly to the landlady a contribution to his rent assessed according to means, and the local authority made up the difference. In the period 1962 to 1965, 120 patients were placed, and the average total cost

\footnotetext{
1 Jones, K. S., and Milne, V. M., Brit. Hosp. F. soc. Serv. Rev., 1966, 76, 159.

2 Morgan, P., Mth. Bull. Minist. Hlth Lab. Serv., 1964, 23, 224.

Annual Report of the Medical Officer of Health for 1967, Exeter. 1968.

- Wright, S. L., Publ. Hlth (Lond.), 1966, 80, 164.

Brown, G. W., Monck, E. M., Carstairs, G. M., and Wing, J. K., Brit. f. prev. soc. Med., $1962,16,55$.

Report of Committee on Local Authority and Allied Personal Social Services, para. 340 , 1968. H.M.S.O.

- Laugharne, J. R. Case Conference and A.S.W. News, 14, 350.
}

to the local authority, including administration, was $£ 27 \mathrm{~s}$. a week per patient.

Fortunately the majority of patients discharged from mental hospitals live at home with their relatives, though it has been suggested that some patients suffering from schizophrenia might be better living with strangers. ${ }^{5}$ If boardingout schemes are to be extended, there must be close supervision of both landlady and patient by social workers who are part of a joint social work team serving both the hospital and local authority, otherwise prompt return to hospital for any patient who relapses and needs attention will not be available. As the Seebohm report recently emphasized, "There must be no danger of neglect outside the hospital replacing the imaginative and skilful care now provided inside many of them."s But, since the same report recommends that responsibility for community social services for the mentally disordered should be included in the proposed new social services department, it is difficult to see how adequate liaison with the hospital will be maintained.

Any large-scale expansion of boarding-out of the mentally handicapped must be viewed critically, for much Victorian mental-health legislation was inspired to control the abuse of the "private mad-house" system. But in view of the problems of child care officers in finding homes for normal children $^{7}$ it seems unlikely that there will be any great demand from landladies for middle-aged mentally handicapped lodgers.

\section{Centenarius Scandinavicus}

Bursting with the spirit of inquiry into natural phenomena, the European countries in the nineteenth century saw the foundation of many journals to record the new and exciting observations. Some of these publications still survive, often with a change of title, a greater girth, a more recondite content, and, such is the toll of time, a new editor. Now joining the Lancet and the B.M.F. as a centenarian is the journal we know as Acta Medica Scandinavica, which began in 1869 as Nordiskt Mediciniskt Arkiv.

The founder and first editor of the journal was Axel Key, professor of pathological anatomy at the Karolinska Institute in Stockholm. According to an account of his work in the current issue ${ }^{1}$ he thought the institute was somewhat overshadowed by the universities, notably Uppsala, and that a journal to publish the papers of its members would stimulate them to scientific activity. Such a reason for founding a journal seems entirely appropriate to those spacious days, though now so many pour from the presses that to start one for which there is not an established need is more likely to deserve censure than commendation. However, it was thought that " the incentive would then exist for one and all to provide matter for the journal, and failure to do so would be felt as a neglect of duty." So in 1863 a journal called Medicinskt Arkiv, of which Key was one of three editors, began publication of papers from the institute.

But Key soon had bigger plans and began to think about a journal for all the Scandinavian countries. This idea won support at a meeting in 1868, and the following year saw the closure of the old journal and the birth of its successor,

\footnotetext{
1 Strandell, B., Acta med. scand., 1969, 185, 1.
} 
which survives to this day. At that time the articles were written in Latin, still the lingua franca of medical men, at least on the Continent. Today British readers can be grateful that English has attained an almost similar status in scientific communication, and nearly all the articles in the Acta are in our language. An effort was made from the start " to maintain the journal on a high scientific level and with diversified contents." The many British readers who consult it will join with us in congratulating its editors on continuing to achieve that aim today.

\section{Treatment of Hyperlipidaemia}

The term hyperlipidaemia implies an excess of lipid substances in the blood. Plasma lipids comprise free and esterified cholesterol, triglycerides, and phospholipids, together with a small but metabolically active free fatty acid fraction. Levels of plasma cholesterol and triglyceride can be readily estimated by conventional chemical techniques and are invariably raised, singly or in combination, in all hyperlipidaemic states. Lipids in the plasma are bound to protein, and these lipoproteins may be separated and characterized electrophoretically and by ultracentrifugation. Knowledge of the lipoprotein fraction present has proved invaluable in classifying and understanding the hyperlipidaemias.

Raised levels of plasma lipids are frequently found in a number of conditions-notably diabetes mellitus, the nephrotic syndrome, pancreatitis, and alcoholism. The treatment of these secondary hyperlipidaemias is that of the primary disease.

The primary hyperlipidaemias comprise a number of diseases with a genetic basis. The syndromes associated with them overlap to some extent, so that an exact classification of these disorders. has not yet been achieved. Xanthomata may make the hyperlipidaemic patient consult a dermatologist, or premature atherosclerosis may take him to a physician with cardiovascular complications. But the diagnosis may be made in an overtly healthy person whose serum cholesterol is estimated in the course of a routine medical examination.

Treatment of hyperlipidaemia is often unsatisfactory. This may be because of difficulty in reaching a precise diagnosis or because of the failure of some hyperlipidaemias to respond to the available treatment. Moreover, there may be some uncertainty about the usefulness of embarking on lifelong therapy the value of which in reducing cardiovascular complications is not clearly established.

The classification of both primary and secondary hyperlipidaemias has been placed on a more rational basis by $D$. S. Fredrickson and colleagues. ${ }^{1}$ They divided patients with hyperlipidaemia into five groups on the basis of lipoprotein analysis by electrophoresis and analytical ultracentrifugation. It seems probable that a classification on this basis will replace such terms as essential familial hypercholesterolaemia, ${ }^{2}$ essential hyperlipaemia, ${ }^{3}$ and fat-induced and carbohydrateinduced hyperlipaemia. ${ }^{4}$

Assessment of the effects of treatment should ideally include quantitative measurements of the main plasma lipoprotein fractions. E. H. Strisower and colleagues ${ }^{5}$ have recently reported such a study. They also divided their patients into five groups on the basis of lipoprotein analysis, but their groups differed in some respects from those of Fredrickson and his colleagues. ${ }^{1}$ Group 1 showed raised Sf $0-12$ lipoprotein levels ( $\beta$ lipoprotein; low-density lipoproteins) with normal or low Sf $20-400$ levels (pre- $\beta$ lipoprotein; very low density lipoproteins). All patients in this group had tendon xanthomata and many showed arcus senilis. Group 2 patients had a similar lipoprotein pattern but did not have tendon xanthomata and differed in their response to clofibrate. Groups 1 and 2 correspond to Fredrickson's type II hyperlipoproteinaemia. Patients in group 3 showed an increase of Sf 12-20 and Sf 20-400 levels, together with tuberous xanthomata. Group 4 comprised patients with raised Sf $20-400$ levels, moderately low Sf 0-12 and normal Sf 12-20 levels. Localized tuberous xanthomatous lesions were not seen in this group, but transient eruptive xanthomata occasionally developed in association with severe diabetes. Group 5 included patients with raised Sf $0-20$ and Sf $20-400$ levels. Strisower and his colleagues did not have any patients with the rare condition of fatinduced hyperlipoproteinaemia in their study.

The five groups differed in their response to treatment. The different types of treatment given were supplementary corn oil, carbohydrate restriction, thyroid preparations, and clofibrate. Patients in Group 1 did not respond to diet or to clofibrate, but showed moderate falls in Sf 0-20 levels with large doses of D- and L-thyroxine. Group 2 patients differed from Group 1 in responding moderately to clofibrate and to thyroid. Group 3 patients showed an excellent response to clofibrate, and this was considered to be the best treatment for this group. Group 4 patients showed large falls in Sf 20 400 levels both with carbohydrate restriction and with clofibrate, but the latter drug produced concomitant rises in Sf 0-20 levels. Because of this finding, carbohydrate restriction was considered preferable in this group. Group 5 patients responded best to combined therapy with thyroid and clofibrate.

The study thus confirmed earlier observations that raised $\beta$ or low-density lipoprotein levels are relatively refractory to treatment with clofibrate, while raised pre- $\beta$ or very lowdensity lipoproteins respond well to both carbohydrate restriction and clofibrate. ${ }^{4} 7$ This must be qualified by the interesting observation that some patients showed concomitant rises in Sf 0-20 levels an clofibrate. Some evidence suggests that this lipoprotein fraction may be more atherogenic than the very low-density lipoproteins. ${ }^{8}$

Studies of this type depend on ultracentrifugation, a technique not available to most physicians concerned with the treatment of hyperlipidaemia. However, a working diagnosis may usually be reached by a clinical assessment of the type and distribution of xanthomata, if present ; by examination of plasma for lactescence after a meal; by estimation of plasma cholesterol and triglyceride, with calculation of the

1 Fredrickson, D. S., Levy, R. I., and Lees, R. S., New Engl. f. Med., $1967,276,34,94,148,215,273$

Wilkinson, C. F., Hand, E. A., and Fliegelman, M. T., Ann. intern. Med., 1948, 29, 671.

Harrison M. T. and Goldberg, D. M., F. Atheroscler. Res., 1963, 3,

561 .
Ahrens, E. H., Hirsch, J., Oette, K., Farquhar, J. W., and Stein, Y., Arrens, E. H., Hirsch, Phycns, 1961, 74, 134.

Trans. Ass. Amer. Phycns, 1961, 74, 134 .
Strisower, E. H., Adamson, G., and Strisower, B., Amer. F. Med., 1968, 45, 488.

- Howard, R. P., Alaupovic, P., Brusco, O. J., and Furman, R. H., f. Atheroscler. Res., 1963, 3, 482.

Strisower, E. H., F. Atheroscler. Res., 1963, 3, 445.

Gofman, J. W., Young, W., and Tandy, R., Circulation, 1966, 34, 679.

- Lees, R. S., and Hatch, F. T., F. Lab. clin. Med., 1963, 61, 518

Brit. med. f., 1968, 3, 689.

2 M.R.C. Research Committee, Lancet, 1968, 2, 693

2 Leren, P., Acta med. scand., 1966, suppl. 466. 